\title{
Review
}

\section{A democratic bearing: Admirable citizens, uneven injustice, and critical theory}

\author{
Stephen K. White \\ Cambridge University Press, Cambridge, 2017, xxiv+217pp., \\ ISBN: 978-1-107-16847-3
}

Contemporary Political Theory (2021) 20, S67-S70. https://doi.org/10.1057/s41296019-00374-4; published online 26 November 2019

Critical theory is needed in the world today. As populists gain support across Western societies, and the disenchanted turn against scapegoated 'others' to voice their frustration, the future of democracy is at stake. Stephen K. White gives us a powerful account of the dynamics that explain movements such as Tea Party and Trump supporters in the US and Brexiteers in the UK, but also a vision of how a new 'democratic bearing' - an ethics of deep concern for human dignity from which springs an orientation towards democracy and inclusivity-might take hold of these societies once again. Revisiting as well as revising Habermas' theory of communicative action, he rescues traditional Frankfurt School critical theory from a place of abstractness and impenetrability to turn it into nothing less than a way out of the most pressing political crisis of today.

The basis of White's argument is a rich philosophical account of how latemodern capitalism brings out feelings of resentment and self-righteousness among the middle segment of society. Drawing on William Connolly's problematic of 'identity/difference'-an ontological relation of a mutually constitutive relationship, such that one person's or group's creation of identity necessarily implies the constitution of a contrasting 'other' entity-he argues that there is a constant, ineliminable dimension of existential threat and anxiety to the human condition. This anxiety in turn implies a persistent susceptibility to hostility and resentment towards the 'other' that threatens one's identity and acts as a reminder of one's mortality. The precarity resulting from globalisation has particularly heightened this sense of threat and 'colonisation', undermining middle-class individuals' sense of security and thus increasing their innately and existentially felt hostility towards those perceived to be the cause of social insecurity-such as the poor and immigrants. Thus, the rise of movements such as that of the Tea Party in the US, and the widespread attitudes towards immigrants in many Western societies, can be explained as essentially a psychological 'fight or flight' reaction (see p. 106) by

(c) 2019 Springer Nature Limited. 1470-8914 Contemporary Political Theory Vol. 20, S2, S67-S70 
those seeking to escape an inescapable sense of finitude. Unwilling to correctly identify concentrations of corporate power and unprecedented economic inequality in societies such as the US as the actual sources of insecurity (p. 39), these movements are continually drawn towards simpler, immediately identity-affirming stances, such as a type of 'constitutional fundamentalism' that purports to preserve the old conditions of liberal democracy (for example, by reference to the Founding Fathers), but excludes and scapegoats the 'other'. The recent rise in populism, then, is but a symptom of this underlying 'syndrome of perception and affect' that marks a constant threat to inclusive democracy, but is particularly pronounced in the conditions of late-modern capitalism (p. 34).

From this understanding of political life as generally and persistently affected by the extent to which anxiety and hostility arise out of citizens' identity formation processes follows a particular framing of the prospects for democracy. Democracy will persist to the extent political practices are developed that lessen this innate propensity towards 'fight and flight' because of which people denigrate and disempower 'the other'. In this spirit, White sets out to formulate a basis for inclusive democracy in late modernity that engages this underlying ontology and psychological dynamic. He does this in three steps: by developing a set of alternative moral sources of the modern self (including human dignity conceived as respect for autonomy and the moral equality of voice, and faith in 'being as becoming' as opposed to a fixed theistic order) that do not rely on either a theistic source or on 'othering'; painting the picture of what he terms an 'exemplary ontological scene' (p. 57) as an image of what intersubjective political communication can then look like; and describing the 'democratic bearing' this can motivate in individuals, despite the inescapable context of threats to one's security and identity. A 'democratic bearing' is an aspirational conception of citizenship, in which subjects are drawn towards a political ideal of deliberative, inclusive selfgovernment, as opposed to populist politics, exclusion and a hunt for scapegoats.

The bearing that can turn the underlying human condition of finitude and threat (what White summarises with the notion of 'dearth') away from 'fight or flight' and towards a commitment to democracy is the simultaneous employment of a 'hermeneutic of suspicion' and one of 'affirmation'. White's account of a democratic bearing thus starts with Habermasian critical theory, but revises it by adding to it those further details which the ontology of 'identity/difference' shows to be needed. On the one hand, White adds to the well-known dimension of 'yessaying' in Habermas's own 'exemplary scene' of communicative action (the ideal speech situation) a simultaneous dimension of 'no-saying' or agonism, which he cogently argues, against all those who have criticised it 'as one large consensus machine' (p. 157), to have been a core, albeit somewhat hidden, component of Habermas's communicative paradigm all along. On the other hand, he adds a 'hermeneutic of self-suspicion', to counter what individuals must recognise in themselves as the innate, ineliminable tendency towards affirming their own 
identity by disempowering others. The resulting 'political tack' expected of deliberative democratic citizens (as of critical theorist scholars) is thus at once more agonistic and more (in White's words) 'chastised' than previous accounts of Habermasian critical theory and deliberative democracy. White powerfully disarms the long-standing critique of Habermas as overly idealist and consensus-oriented, precisely by highlighting the acknowledgement that can already be found in Habermas's writings of the insufficiency of communicative reason (p. 159) as an integral part of his overall communicative paradigm. Habermas is aware that democracy remains forever imperfect, as new claims, identities and settings continually re-open the fundamental tension between law and legitimacy. This means there is a central role not just for discursive 'no-saying' in an idealised sense as part of a process towards consensus, but for civil disobedience that bears witness to the imperfection of even the most mature democracies (pp. 157-159).

What White's revisions also do to Habermasian critical theory is to turn its powerful vision and normative resources for democratic politics away from the foundationalism implicit in Habermas's account of communicative action-where it is based on the presumption that 'reaching understanding is the inherent telos of human speech' (p. 123). White seeks to render communicative action entirely nonfoundationalist by replacing any natural telos inherent in language with moral sources that can inspire a faith in (not truth of) this kind of engagement in those afflicted by the fundamental problematic of the identity/difference dynamic and the anxiety this causes. In a sense, White succeeds in substituting the allegedly 'ideal citizens' that critics of Habermas (wrongly) imagined his ideal speech situation to require-fully rational and committed to finding consensus-with a scene of communicative action populated by nothing less than the most 'real', vulnerable citizens - the populists, the self-righteous but irrational 'trouble makers' of today. Because it is this psychological, affective problem that underlies late-modern threats to democracy, the purely secular accounts of liberal political theory do not provide sufficient resources for an alternative ethos.

This is perhaps the most interesting - and daring-part of this account: its rootedness in faith in democratic engagement. For White, faith is an important component of the democratic prospect inasmuch as something as powerful as a deep yearning for meaningful experience underpins the reason why democracy is under threat in late-modern societies (pp. 88-89). Rather than suppressing this yearning, he argues it can be cultivated towards supporting a sense of 'fullness' (as opposed to 'dearth' and finitude) in line with and generative of democratic engagement. In a brilliantly original move, White argues grounding the argument for democracy in faith-as opposed to the ostensible certainty of pure reason-is the key to accepting and embracing the unsettling human finitude, which would otherwise be 'fought or fled' in destructive ways. While we innately crave the security of truth and consensus, reminding ourselves of, and embracing, their impossibility and banking on faith instead, is what actually resolves the underlying

(c) 2019 Springer Nature Limited. 1470-8914 Contemporary Political Theory $\quad$ Vol. 20, S2, S67-S70 $\quad$ S69 
problem of anxiety. In contrast to an insistence on the truth of one's own perceived order by denigrating some 'other', this then allows for what White calls an ethos of an 'attentive traveller-host' (p. 69). Within this ethos, individuals will be willing to 'travel' outside of their own comfort zone into the 'neighbourhood' of the other, as well as playing the role of 'host' to the other in the form of the kind of 'presumptive generosity' needed for faith in democracy. At the current time of booming 'democratic innovations' via institutional design, this account of an ethos of suspicion and self-suspicion, no-saying as well as listening, at the heart of what constitutes a deliberative democracy is encouragingly ground-breaking and profound.

To the extent that this argument rests on faith, however, it is also fragile. Will this vision indeed reach our societies, or have its very foundations already been eroded? While I must caution against White's idea to 'plant' such a new ethos (p. 105)—anyone's ability to purposely 'plant' something as far-reaching as an individual's sense of meaning would itself constitute significant domination-it is the hope inherent in this book itself that is a much-needed resource for the faith in democratic renewal White envisions. In the troubled times we live in today, reading of a vision of politics that pursues deliberative democracy out of a deep concern for human dignity; that succeeds in weaving individuals' yearning for autonomy and identity together with listening and generosity towards others; and that can therefore optimistically embrace openness and change but also remain forever alert towards any exclusion, injustice and domination makes for powerful inspiration indeed.

Marit Hammond

Keele University, Keele ST5 5BG, UK m.hammond@keele.ac.uk 